\title{
ENDONYMIC PLACE-NAME ALTERNANTS AND THEIR CULTURAL SIGNIFICANCES
}

\author{
RICHARD COATES \\ University of the West of England, Bristol
}

\section{AB S T R AC T}

Many places have more than one simultaneously current name within the same linguistic community, usually an official one and at least one unofficial one. In England, there are several sources of place-name alternation, and the first purpose of this paper is to categorize them. In most cases, where there is a clearly unofficial form it can be simple-mindedly characterized as the form used by local people with local people in a way which asserts their shared identity and community values. In some cases, alternating usage is well entrenched, and serves stylistic ends. Where there is instability of usage, the direction of change is almost always in favour of a spelling-pronunciation. But there is sufficient evidence that simplistic assessments of the situation in England are inappropriate, and some cases are discussed which pose difficulties for the idea that informal alternants have always been produced by the same kinds of historical process.

\section{[1] INTRODUCTION}

In his novel Maps for lost lovers (Aslam 2004), Nadeem Aslam writes of a fictional town in the north of England known to its Urdu-speaking inhabitants as Dasht-eTanhai 'wasteland of loneliness', apparently in allusion to a poem by the Pakistani poet Faiz Ahmed Faiz. They also refer to other local places using names which have resonances of southern Asia. Much has been written about such use of different names for the same place by members of different language-communities, including the relation between endonyms and exonyms, as illustrated for example by Köln vs. Cologne (with the latter used only outside the place and indeed outside its country), or Chennai vs. Madras (with both names in competition locally for the right to denotational primacy). ${ }^{1}$ There is much less in the literature about the use of place-name variants by members of the same language-community, although very interesting and systematic work has been done has been done, for example,

[1] We might call this "right" to denotational primacy kyrionymy, following the spirit of Fred W. Householder's technical term kyriolexia (Householder 1983) - the kyrionym is the name accepted as the "real", often but not necessarily official, name of the place. 
on the alternative local toponymy of Helsinki by Terhi Ainiala and Jani Vuolteenaho (Ainiala \& Vuolteenaho 2006; Ainiala 2008). Such culturally and stylistically significant variation involving paired endonyms (which may shade into the Chennai/Madras type of case when the latter is no longer perceived as a matter of bilingualism) is the topic of the present paper, and names in England are the object of investigation. ${ }^{2}$

\section{[2] ALTERNATION OF ENDONYMS}

A number of English places have more than one name simultaneously current among English-speakers. In such a set of names, one can usually be characterized as official and at least one as unofficial, though the facts may not always be as straightforward as that. It is certainly true that different significances of some kind attach to such alternating names. There are at least seven broad types of alternation, set out below. Throughout this article, A $\sim \mathrm{B}$ means 'A alternates with $B$ '. The differences which are exploited in the alternation often, but by no means always, arise from change in the spoken form whilst the written form remains unchanged, with the new spoken form then competing for written status (and therefore kyrionymy; see note 1); or conversely, a new transparent pronunciation develops from the written form. Accordingly, type 6 below is probably the most frequent, but that is just an impression and no proper count has been done.

Sometimes in popular writings long-standing alternative names are listed alongside apparent nonce-forms (like Seaton Carew $\sim$ Seaton Canoe created in response to the faked disappearance of a man who abandoned his canoe on the beach there in 2002), including both puns and other sorts of joke (like Wavertree $\sim$ Shake-a-bush). I have avoided such apparent nonce-forms in this article since I have no idea how widespread their use is, but the same processes are responsible for the creation of some alternative names in both categories. There is also clear evidence for a "system" of place-nicknames having been in use among Citizens' Band radio users (Dills 1981, passim), and I have found patchy evidence for other cases in the usage of people who need to work with place-names regularly, such as railway clerks. I have tried to restrict myself to names which I believe are not confined to special-interest groups, though the criterion is not easy to operate (as in the case of Guz below, (iii)-c).

This paper is not about the kind of variation which is predictable from dialectology. Pudsey can be pronounced with $/ \mathrm{u} /$ or $/ \Lambda /$ in the first syllable, the former being the local spoken form in West Yorkshire, and the latter in effect a spelling-pronunciation based on the norms of Received Pronunciation. Similar

[2] Chennai (sometimes romanized as Chhennai) is the Tamil name. Madras was perceived as Portuguese and therefore colonial, and suffered official replacement in 1996. (In fact, it is Portuguese-mediated Arabic.) See Tharoor (2002). 
considerations apply to Bath with /a:/ or /a/ or /æ:/ (the local form having /æ:/) and Exeter with or without an audible final $/ \mathrm{r} /$ when spoken in isolation (the form with $/ r /$ being local). The names investigated here are those where there is more at stake than mere accent-related variation. Both names may be used by the same speaker or writer in different circumstances and for different effects, for example expressing different aspects of identity. Accent-related variation can of course be manipulated in similar ways; that is simply not the province of this paper.

\section{[3] SOURCES AND CATEgORIES OF ALTERNATION}

In England, there are arguably seven sources, and resultant types, of place-name alternation as just defined. The first five types are sometimes lumped together in popular writings as place-nicknames. This term has also been used in a somewhat distinct sense in an article by Jones-Baker (Jones-Baker 1981), in which adjectivally modified place-names such as Merry Wakefield and Wychwood-Always-Late are the main subject, but such structures are not what this paper is about (with a partial exception under (ii) below, the first example borrowed from Jones-Baker's paper). Not all the names mentioned below are necessarily still in use, but all are well recorded.

(i) Specialization of a categorizing noun in the function of a name par excellence: London $\sim$ Town, Newcastle upon Tyne $\sim$ Toon

She used to work in Town 'she used to work in London'

The Toon Army 'supporters of Newcastle United Football Club'

The two words in question here are both variants of the word town, but are not intersubstitutable, and to that extent function as proper names.

(ii) Specialization of another (grammatically modified) place-name in the function of a name by metaphor:

Tring $\sim$ Little Manchester, West Marsh (Grimsby) Little Russia, Brighton $\sim$ London-by-the-Sea

Some such names are not nicknames but independent place-names, such as Petty France and Little Venice (and indeed Venezuela).

(iii) Application of an expression as a name by some species of metonymy:

(a) Specialization of a referring expression in the function of a name, by metonymy:

London The Smoke (now obsolete); almost analogously Edinburgh Auld Reekie 'old smoky' in Scots 
Canterbury $\sim C T$ (from the letters of its postcode derived from its being a Royal Mail post town)

Cleethorpes $\sim$ Meggies

For discussion of the last, a metonymic application of a term originally denoting the town's inhabitants (cf. Essex and Wales), see Dowling (Dowling 1995, 35) and Coates (Coates 2008, 53-4).

(b) Combining an expression for a circumstance with a generic term for a place, in the function of a name:

Melton Mowbray Pork Pie Town (from its most famous manufacture) Macclesfield $\sim$ Sticky Town (from an event involving treacle spillage) Wokingham $\sim$ Louse Town (from a myth about its mayoral selection method)

Cf. Chicago $\sim$ Windy City, which however seems to have arisen as an onymized version of the expression the windy city (see evidence adduced in Popik (2004)). It shows loss of the definite article, i.e. showing that it originated in a fully-articulated referring noun phrase. I know of no evidence for such a prior phase in the three instances in England, which seem to have originated as names.

In the instances in $3 \mathrm{~b}$., the alternative names originate in an accidental (in the Platonic sense - 'descriptively true but not necessarily so'), incidental or mythical circumstance associated with each place in question, respectively. They might also be viewed, in a sense, as involving metonymy, but they are not purely metonymic expressions; rather the key element - often a noun or adjective - is used as a specifier. For pure metonymy, one would need to find Melton Mowbray $\sim$ Pork Pie, etc. Accordingly, I have proposed a partly separate category.

(c) Pure metonyms where the expression is not in any sense etymologically descriptive of the place:

Devonport $\sim$ Guz, Portsmouth $\sim$ Pompey

These items are not on the face of it what might be called instances of the "factual metonymy" of (iii)-a and (iii)-b, but instances of the application of an expression for a circumstance directly as a name. The first example has been variously explained, but Guz appears to originate in a call-sign identifying a naval radio-station at Plymouth (GZX $=$ Mount Wise radio-station), ${ }^{3}$ geographically near enough to suggest

[3] Dykes, Godfrey, no date. Other radio callsigns of the 1930-1931 period. Online at http://www.godfreydykes.info/other\%20radio\%20callsigns\%20of\%20interest\%201930-31.htm, sourced from "the [?Royal Navy] 1930 book of callsigns" (accessed 15 April 2009). 
metonymy. The second, and particularly complicated, example is explained as fully as is currently possible in Coates (2009), but there is not enough space here to deal with the facts as known.

The names in sub-groups (iii)-b and (iii)-c have in common the fact that the relationship between the alternative name and the place may be locally expressed through folk-onomastic narratives; such narratives may also involve an explanation of the relationship between the alternative name and the official one (as in some variants of the Pompey story). I quite accept that the relation between groups (iii)-a, (iii)-b and (iii)-c is capable of refinement. But they share a property akin to metonymy.

(iv) Use of a morphological variant of the name (1): simple abbreviation by truncation or initialism:

Bristol $\sim$ Briz, Chichester $\sim$ Chi, Skelmersdale $\sim$ Skem

Milton Keynes $\sim \mathrm{MK}$ (if this is not like CT in (iii)-a above)

There are also occasional suggestions of acronymy: a children's group in Westbury-on-Trym is known as WOT'S TOTS.

Bristol is locally pronounced, by some people, though not with the authority of local dialect, /'brizl/, which gives rise to the truncated form Briz (NB pronounced with /z/ not /s/). Chi is pronounced / t ai/. The loss of the /l/ in the truncated form of Skelmersdale represents a continuation of an ancient pattern in English syllable structure (cf. Helmsley, Yorkshire, locally pronounced /'emzli/, and the case of Cholmondeley mentioned below).

(v) Use of a morphological variant of the name (2): abbreviation + affixation:

$$
\begin{aligned}
& \text { Doncaster } \sim \text { Donny, Skegness } \sim \text { Skeggy, Kidderminster } \sim \text { Kiddy, Bed- } \\
& \text { minster } \sim \text { Bemmy, Darlington } \sim \text { Darlo }
\end{aligned}
$$

These exhibit a simple truncated form of the generally-used name plus a suffix, normally $-y$ or $-o$, with occasional phonological adjustments of a kind analogous to that seen in Skelmersdale.

(vi) Use of a phonological variant (1): especially a spelling-pronunciation replacing a local traditional pronunciation which is etymologically related to but phonemically distinct from it

There are cases where the spelt form represents the modern general pronunciation, which competes with the authentic local pronunciation, as in 
Birmingham $\sim /$ 'brumədzəm/ (also reduced to /brum/), Brightlingsea $\sim /$ 'briklsi:/, Pontefract $\sim /$ 'pomfrat/. There are sometimes interpretational complexities in such cases, as with Southwell $\sim$ /'sıðəl/ and Shrewsbury with stressed /au/ $\sim / \mathrm{u}: /$, to both of which we will return below.

Such alternants may become totally onymically separated, with specialization of the competing names to denote different, though adjacent, places, as with Churchdown and Chosen (Hill) in Gloucestershire and Trottiscliffe and Trosley (Country Park) in Kent. In both these instances, the second name in the pair is a phonological development of a form which has come to be represented in writing by the first, and the two have competed, with differing degrees of success, for the territory before being deflected from the main target. Churchdown is now always pronounced as the spelling suggests, whereas Trottiscliffe is still widely pronounced as the spelling of the alternant suggests, /'trauzli/.

Sometimes one alternant becomes lexicalized. In the case of /'brumə$\mathrm{d}$ 孔əm/, the traditional pronunciation gave rise by metonymy to an adjective brummagem meaning 'cheap and flashy' [of goods] (compare pinchbeck and tawdry, both also derived from proper names: a detoponymic surname, and a saint's name used in that of the great medieval fair at Ely). The word is now obsolete, but clearly became detached from its etymological source before disappearing; the name-form Birmingham has not suffered the same pejoration (connotational decline).

(vii) Use of a phonological variant (2): especially a prosodic variant which is hidden by not being represented in the spelling

Following a general English pronunciation rule, Sussex names such as Rottingdean are stressed on the first syllable. However, there is a competing local variant with final stress in names with certain distinctive final elements, including dean, whose history, status and significance are explored fully by Coates (Coates 1980).

A somewhat separate matter is the antiquarian revival of ancient spellings of a name for narrow local purposes. For instance, the name Ormersfield Farm in Dogmersfield (Hampshire), is a modern interpretation of the Domesday spelling of the village-name, Ormeresfelt. This is a scribal mangling of the authentic form that eventually results in Dogmersfield. Strictly speaking the new-old form Ormersfield does not compete with the name of the village; they are not variants or alternative 
names for the same place, but the new-old name is applied to a farm within Dogmersfield and evokes that name for those with sufficient historical knowledge. ${ }^{4}$

\section{[4] ANALYSIS AND INTERPRETATION：USER-GROUPS}

In most of the cases dealt with above, where there is a clearly unofficial form it can be characterized simply as the form used by local people with local people in a way which asserts and reinforces their shared identity and community values. But the unofficial form may operate in the named community alone, or over a wider region (e.g. the relevant county) or user-group, representing the possibility of different levels of, or different criteria for, self-identification. Compare the different user communities of the following names:

- Brighthelmston $\sim$ Brighton (originally a 17th-century local truncation, adopted by the late-18th century smart set who visited the place seasonally; now universal)

- Devonport $\sim$ Guz (not originally local at all; popularized by and among Royal Navy and Merchant Navy personnel, but not widely known by others)

- Doncaster $\sim$ Donny (a hypocoristic apparently of local origin, adopted especially by railway enthusiasts)

- Lawrence Weston $\sim E l$ Dub (a complex re-spelt initialism-cum-truncation, hardly known, and certainly hardly used, outside the physical confines of the community itself and those of local communities with similar social profiles)

[5] ANALYSIS AND INTERPRETATION: LOCALITY AND HUMOUR

Some unofficial forms, but not all, are regarded as humorous - in much the same way as dialect has historically been, and continues to be, treated as a source of humour in England - and may be used "in inverted commas" by non-members of a local in-group who can thereby show local knowledge without identifying themselves wholeheartedly with the place in question.

\section{[6] ANALYSis AND INTERPRETATION: INSTABILITy OF ALTERNATION}

Where there is instability of usage, in the cases of (vi) and (vii), the direction of change is almost always in favour of the spelling-pronunciation. Spelling-pronunciation operates in different ways symbolically and may acquire different cultural meanings; Brightlingsea (Essex) pronounced as the spelling suggests is now

[4] The revival of this name is likely to have been precipitated by the title of the character the Earl of Ormersfield in the novel Dynevor Terrace (Yonge 1857) by the prolific Hampshire author Charlotte M. Yonge, who was born at Otterbourne, a few miles from Dogmersfield. 
general and official whilst the ancient /'briklsi:/ is merely local (if it is still in use at all). On the other hand, Wymondham (Norfolk), if pronounced as spelt, would be universally characterized as an error and a trap for the unwary, because the pronunciation for all people with knowledge of the place, in all circumstances, is the traditional /'windəm/.

The fluctuation of pronunciation in the cases of Southwell and Shrewsbury is a paradoxical problem.

\section{- Southwell (Nottinghamshire)}

Gover et al. (Gover et al. 1940,175) gives only the historically expected local pronunciation /'s $\Lambda$ ðəl/; and this pronunciation is the one heard on national radio and television for the local racecourse, and even more widely for the place's cathedral. But inquiry on the spot reveals that local people now appear to call it /'sau $\theta \mathrm{wel} /$, and refer to /'s $\Lambda$ ðəl/ as the "BBC pronunciation".

- Shrewsbury (Shropshire)

A pronunciation of the name with /au/ (<ow>) in the first syllable is the historically expected one (from OE Scrobbesbyrig), and is therefore the one to be expected locally. Spellings with <ew> are found only from the late 14th century onwards. They are presumably to be compared with the spellingalternation <ew $>\sim<\mathrm{ow}>$ found in lexical words like sew and show. Such spellings must have come to be interpretable as representing /u:/, as in shrew, but unambiguous spellings of the place-name indicating /u:/ appear only from the 1720 s onwards. This appears to be a local development, and it is now the universal local pronunciation. /ou/ is regarded as "upper class" (Gelling 1990, 270), and is the form until recently most often used by outsiders.

These two instances are paradoxical because spelling-pronunciations are, untypically, the local forms, whilst the ancient forms whose pronunciation departs from the spelling are regarded as "foreign" to the place in question or inauthentic. They show that a mechanical account of the cultural meaning of spellingpronunciation is impossible.

Usage at both ends of the social scale may reveal conservatism. There is some suggestion that the older "expected" forms are preserved by the upper class, as in the stereotypical upper-class pronunciation of the surname Cholmondeley /' $\mathrm{y} \wedge \mathrm{mli} /$ (derived from a Cheshire place-name) and the aristocratic title Burlington (from Bridlington, East Riding of Yorkshire); note also Raveningham as /'rævinəm/, a pronunciation "particularly associated with Raveningham Hall", i.e. the aristocratic house in this Norfolk village (Miller 1971, s.n.). On the other hand, spellingpronunciation is typically an innovation of the literate middle classes, and may 
be resisted by locals, including local gentry, in favour of the historical form. This onomastic fact is paralleled by facts about accent, for example the phenomenon of $/ \mathrm{h} /$-dropping, reviled by the literate but stereotypically continued in large areas of England by the local members of the working class (Orton et al. 1978, maps Ph220-1) and until relatively recently in some words (e.g. hotel, humour) by certain members of the aristocracy or gentry (see e.g. Mugglestone 2006, 289).

\section{[7] CONCLUSIONS}

The conclusions to be drawn from this survey of English endonymic alternants are that such forms do not exist in an interpretational vacuum, and that they are culturally significant. Alternating forms may be in use by different user-groups, unsurprisingly, and may acquire social colouring in that way; and one alternant may often be a marker of local in-group identity permitting psychological distinctiveness (as in the social identity theory originally introduced by Tajfel \& Turner (1979)). These meanings allow for their use with different stylistic import (formal vs. informal or familiar). It is noteworthy that the complexity of alternationpatterns in English place-names does not allow the automatic equation of written form or spelling pronunciation with official or socially superior form.

\section{REFERENCES}

Ainiala, T. 2008. Use of toponyms in spoken language: the case of Vuosaari in Helsinki. In Wolfgang Ahrens, Sheila Embleton and André Lapierre eds. Names in Multi-Lingual, Multi-Cultural and Multi-Ethnic Contact. Proceedings of the 23rd International Congress of Onomastic Sciences, Toronto: York University. Compact disc.

Ainiala, T. \& J. Vuolteenaho. 2006. How to study urban onomastic landscape? Acta Onomastica 47.58-63.

Aslam, N. 2004. Maps for lost lovers. London: Faber and Faber.

Coates, R. 1980. A phonological problem in Sussex place-names. To mark the 50th anniversary of the formulation of the problem. Beiträge zur Namenforschung (neue Folge) 15. 299-318.

Coates, R. 2008. Reflections on some Lincolnshire major place-names, part 1: Algarkirk to Melton Ross. Journal of the English Place-Name Society 40. 35-95.

Coates, R. 2009. Pompey as the nickname for Portsmouth. Nomina 32.59-73.

Dills, L. 1981. The 'official' CB slanguage language dictionary. New York: Burrows and Baker.

Dowling, A. (ed.). 1995. Egging back o' Doigs: a glossary of words and expressions used in Grimsby, Cleethorpes and district. Hull: University of Hull (Centre for Continu- 
ing Education, Development and Training), on behalf of Doughty Centre Local History Group [Grimsby].

Gelling, M. 1990. The place-names of Shropshire, vol. 1, vol. (Survey of English PlaceNames vol. 62/3 [double vol.]). Nottingham: English Place-Name Society.

Gover, J.E.B., A. Mawer \& F.M. Stenton. 1940. The place-names of Nottinghamshire. Cambridge: Cambridge University Press. (Survey of English Place-Names vol. 17).

Householder, F. W. 1983. Kyriolexia and language change. Language 59. 1-17.

Jones-Baker, D. 1981. Nicknaming in the popular nomenclature of English places. Nomina 5. 57-61.

Miller, G.M. (ed. \& transcr.). 1971. BBC pronouncing dictionary of British names: with an appendix of Channel Islands names. Oxford: Oxford University Press.

Mugglestone, L. 2006. English in the 19th century. In Lynda Mugglestone (ed.), The Oxford history of English, 274-304. Oxford: Oxford University Press. Chapter 10.

Orton, H., S. Sanderson \& J. Widdowson (eds.). 1978. The linguistic atlas of England. Beckenham: Croom Helm, etc.

Popik, B. 2004. Windy City (summary).

http://barrypopik.com. Posted 11 October 2004, accessed 17 April 2009.

Tajfel, H. \& J. Turner. 1979. An integrative theory of intergroup conflict. In William G. Austin and Stephen Worchel (eds.), The social psychology of intergroup relations, 94-109. Monterey, CA: Brooks-Cole.

Tharoor, S. 2002. In India's name game, cities are the big losers. International Herald Tribune, 6 September, 2002. http://www.shashitharoor.com/articles/iht/name-game.php.

Yonge, C.M. 1857. Dynevor Terrace: or, the clue of life. London: Macmillan.

AUTHOR CONTACT INFORMATION

Richard Coates

Bristol Centre for Linguistics

University of the West of England

Bristol BS16 1QY

UK 